
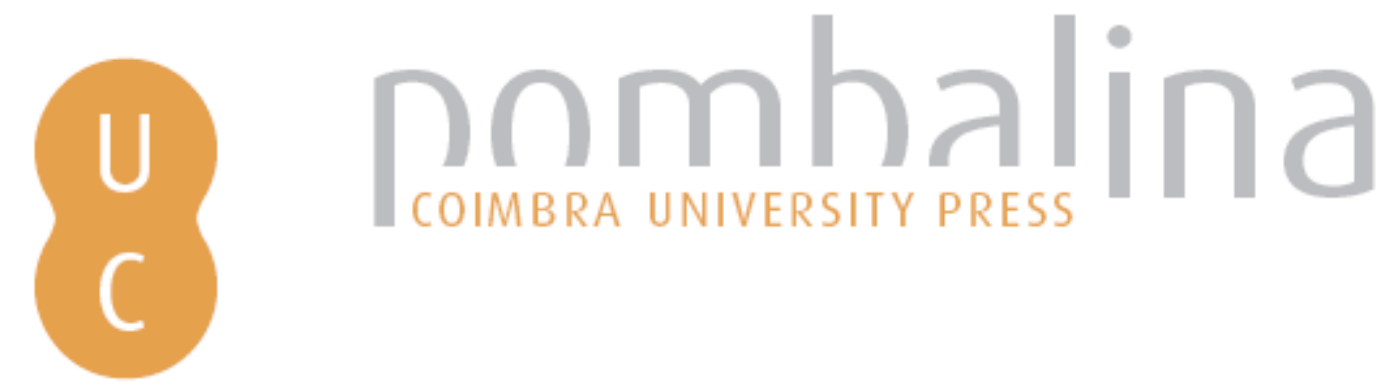

\title{
Assessing fire severity using charcoal reflectance following a recent heathland wildfire on Carn Brea, Cornwall, UK
}

Autor(es): $\quad$ New, Stacey L.; Hudspith, Victoria A.; Belcher, Claire M.

Publicado por: Imprensa da Universidade de Coimbra

URL

persistente: URI:http://hdl.handle.net/10316.2/44667

DOI: $\quad$ DOI:https://doi.org/10.14195/978-989-26-16-506_150

Accessed : $\quad$ 26-Apr-2023 15:26:38

A navegação consulta e descarregamento dos títulos inseridos nas Bibliotecas Digitais UC Digitalis, UC Pombalina e UC Impactum, pressupõem a aceitação plena e sem reservas dos Termos e Condições de Uso destas Bibliotecas Digitais, disponíveis em https://digitalis.uc.pt/pt-pt/termos.

Conforme exposto nos referidos Termos e Condições de Uso, o descarregamento de títulos de acesso restrito requer uma licença válida de autorização devendo o utilizador aceder ao(s) documento(s) a partir de um endereço de IP da instituição detentora da supramencionada licença.

Ao utilizador é apenas permitido o descarregamento para uso pessoal, pelo que o emprego do(s) título(s) descarregado(s) para outro fim, designadamente comercial, carece de autorização do respetivo autor ou editor da obra.

Na medida em que todas as obras da UC Digitalis se encontram protegidas pelo Código do Direito de Autor e Direitos Conexos e demais legislação aplicável, toda a cópia, parcial ou total, deste documento, nos casos em que é legalmente admitida, deverá conter ou fazer-se acompanhar por este aviso.

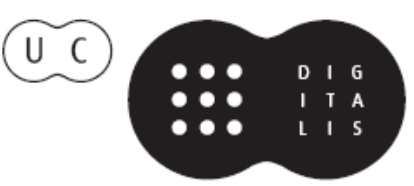




\section{ADVANCES IN}

\section{FOREST FIRE RESEARCH}

\section{8}

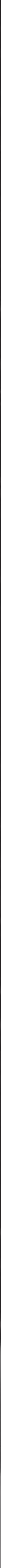


Short contribution - Fire Management

\title{
Assessing fire severity using charcoal reflectance following a recent heathland wildfire on Carn Brea, Cornwall, UK
}

\author{
Stacey L. New*, Victoria A. Hudspith \& Claire M. Belcher \\ wildFIRE Lab, Hatherly Laboratories, University of Exeter, Exeter, EX4 4PS, \\ United Kingdom \{S.New@exeter.ac.uk*\}
}

\begin{abstract}
Charcoal has recently been suggested to retain information about the fire that generated it (Belcher and Hudspith, 2016). When looking under a microscope charcoals formed by different aspects of fire behaviour indicate different ability to reflect the amount of light when studied using the appropriate technique. It has been suggested that this method might be able to provide a quantitative fire severity metric that can be used in conjunction with or instead of standard qualitative fire severity scores. We studied charcoals from a recent wildfire in Carn Brea, Cornwall and assessed whether charcoal reflectance (Ro) can be linked to standard qualitative fire severity scores for the burned area. We found that charcoal reflectance was greater at sites along the burned area that have been scored as having a higher fire severity, whilst surrounding sites with a lower severity score have a noticeably lower Ro measurement. We suggest, by measuring the reflectance of charcoals that this may be able to provide quantitative information about the spatial distribution of heat across a burned area post-fire, and that this should provide better linkages between fire behaviour, fire severity and ecosystem effects.

Synthesis: Results from the analysis of the Carn Brea charcoal suggests that variation in charcoal reflectance measurements may be due to changes in fire severity across a burn site, enabling researchers to gain information that links fire severity and fire behaviour by analysing the charcoal left behind post-fire. This is particularly useful if quantitative fire severity measurements cannot be obtained via remote sensing.
\end{abstract}

Keywords: Charcoal, Reflectance, Severity, Surface Fire, Surface Fuels

\section{Introduction}

Charcoal is a key product of wildfires that remains in abundance after wildfire events. Researchers have established that the structure of charcoal varies during creation due to a number of differing factors e.g. wood species, wood density and heating (Cohen-Ofri et al., 2006; Lowden and Hull, 2013). Experimental research has indicated that during the combustion process charcoal transitions through various phases in which cells are eventually re-ordered to a more graphite-like structure (Cohen-Ofri et al., 2006; Belcher and Hudspith, 2016). This re-ordering of cells alters the reflective properties of the charcoal i.e. there is an increase in the quantifiable amount of light reflected from the surface of the charcoal, thus, allowing researchers to study the reflectance properties of charcoal (Belcher and Hudspith, 2016).

Recently, researchers have begun to develop the use of charcoal reflectance in post-fire assessments, (e.g. Belcher and Hudspith, 2016; Hudspith et al., 2017). Here we consider the use of charcoal reflectance as a tool in post-fire assessments as a quantitative measure of fire severity. We present reflectance measurements in combination with standard qualitative fire severity scores from a recent wildfire which occurred in Carn Brea, Cornwall $\left(50.2141^{\circ} \mathrm{N}, 5.2551^{\circ} \mathrm{W}\right)$. Using both a fire severity matrix across the burn scar, acquired in the field, and charcoal reflectance, conducted in the laboratory, we consider whether charcoal reflectance may serve as a quantitative fire severity measure in place of, or in combination with the qualitative fire severity matrices. 


\section{Methods and Materials}

\subsection{Site and Material Collection}

A heathland fire in a region dominated by heather (Calluna sp.) and gorse (Ulex europaeus) occurred on the $26^{\text {th }}$ of May 2015 burning 7 hectares of a small area of Cornwall, UK (BBC, 2015). The gorse in particular had been left unmanaged, meaning that it was overgrown and dense (The Heritage Journal, 2015), this resulted in a large abundance of fuel on the heathland for the fire to burn. The fire started at the bottom of the site and travelled up the hill to the top where a footpath intersected the heathland; this may have acted as a 'natural' fire break. Charcoal samples were collected from the burn scar in June 2015, two days after the fire. A transect was taken across the axis of the fire scar and 12 sampling locations documented using a GPS and photographs. Charcoal samples were collected every $\sim 1 \mathrm{~m}$. At each sampling location a $30 \mathrm{~cm}$ by $30 \mathrm{~cm}$ quadrat was placed on the ground and charcoal collected from within that area. A mixture of heather and gorse charcoal was collected.

\subsection{Fire Severity}

Qualitative fire severity scores were assigned to each sampling location according to the table presented in Ryan and Noste (1985) but was modified for a heathland ecosystem (see Hudspith et al., 2014). Fire severity was found to be similar across the entire transect, but became higher in the denser, more overgrown gorse-dominated areas. Of the 12 sampling locations along the transect 10 were classified as having a light fire severity (severity score 3), 'surface litter, mosses and herbs charred or consumed', the two remaining sampling locations were given a moderate or severe fire severity description (severity score 4) which includes 'all understory plants charred or consumed, fine dead twigs on soil surface consumed, pre-fire soil organic layer largely consumed' (Hudspith et al., 2014).

\subsection{Reflected Light Microscopy}

Reflected light microscopy was used to assess the reflectance of the charcoals collected along the transect. All charcoal samples were oven dried at $40^{\circ} \mathrm{C}$ before preparing for analysis under the reflectance microscope. Charcoal samples, a mixture of vegetation types (heather and gorse), were embedded in polyester resin blocks and subsequently ground and polished using a MetaServ 250 with Vector Power Head grinder-polishing machine (Buehler, Neckar, Germany), with a silicon

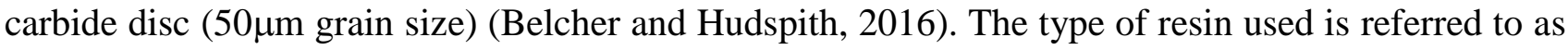
cold-mounting epoxy resin, consisting of two components, an adhesive and a hardener. Reflectance was measured using a Zeiss Axio-Scope A1 optical microscope with a TIDAS-MSP 200 system attached. The TIDAS-MSP 200 system is calibrated using three synthetic reflectance standards, strontium titanite $(5.41 \%$ reflectance in oil (Ro)), gadolinium gallium, garnet (GGG) (1.719\% reflectance in oil (Ro)) and spinel (0.42\% reflectance in oil (Ro)) (Belcher and Hudspith, 2016). An x50 objective (with x32 eyepiece magnification) was used and the measurement of reflectance was manually taken at the cell-wall junction using MSP200 v 3.27 software (Belcher and Hudspith, 2016), 100 reflectance measurements were taken per block.

Reflected-light microscopy allows charcoal to be visually analysed whilst also being able to quantitatively measure the amount of light that is reflected back from the polished charcoal surface; the brighter the charcoal appears under the microscope the more light is being reflected back (Figure 1) (Belcher and Hudspith, 2016). 

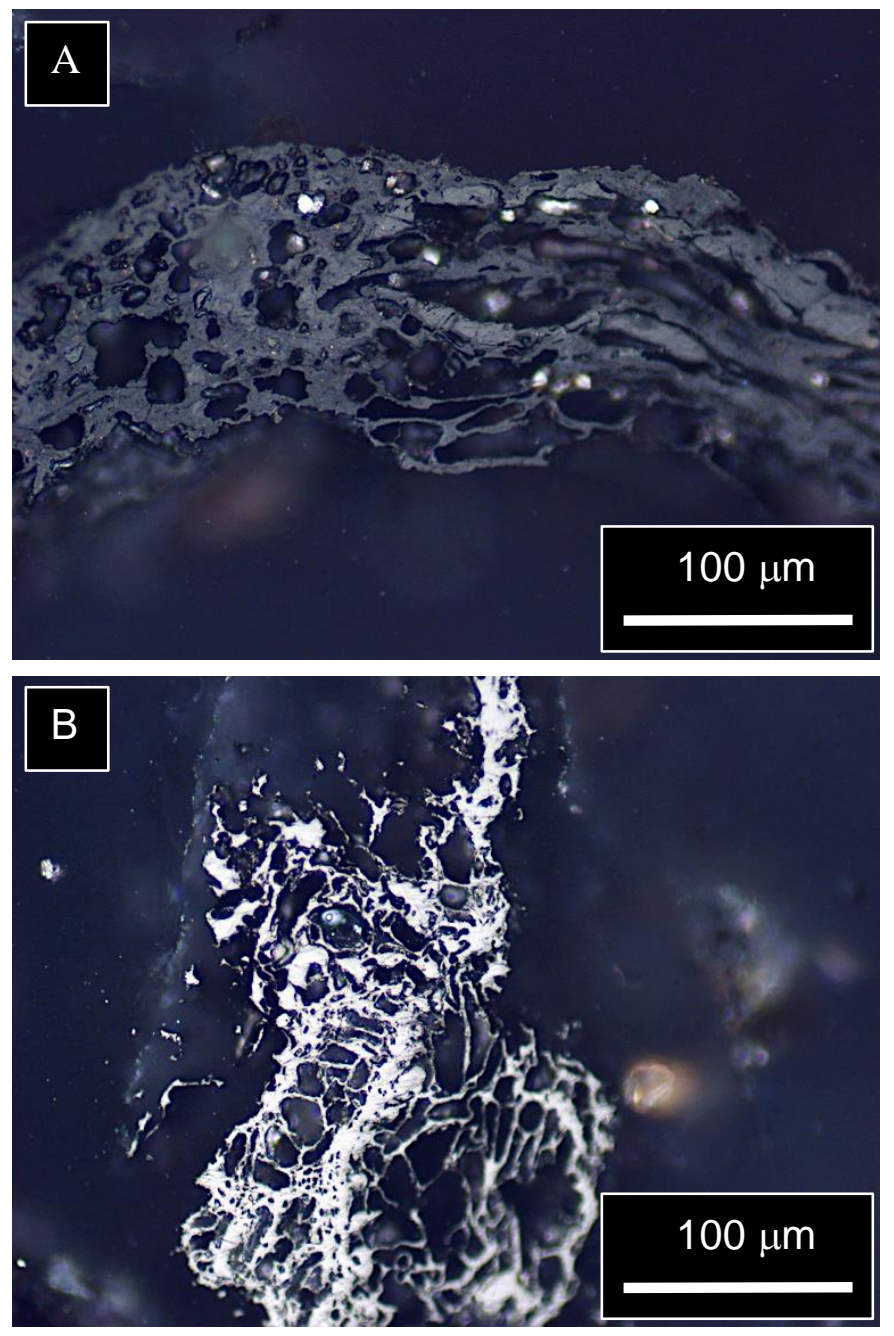

Figure 1-Images of charcoal under the reflectance microscope. A) Shows a lower reflecting piece of charcoal from a location along the burn scar given a severity score of 3 in the field, and B) shows a higher reflecting piece of charcoal from a location along the burn scar given a severity score of 4 in the field.

\section{Results and Conclusions}

We observed that locations along the burn scar that experienced higher qualitative fire severity scores produced charcoals that were more higher reflecting when compared to those at lower severity sites (Figure 2). Images of charcoal showing this visual difference in reflectance, under the reflectance microscope, are shown in Figure 1. 


\section{Carn Brea}

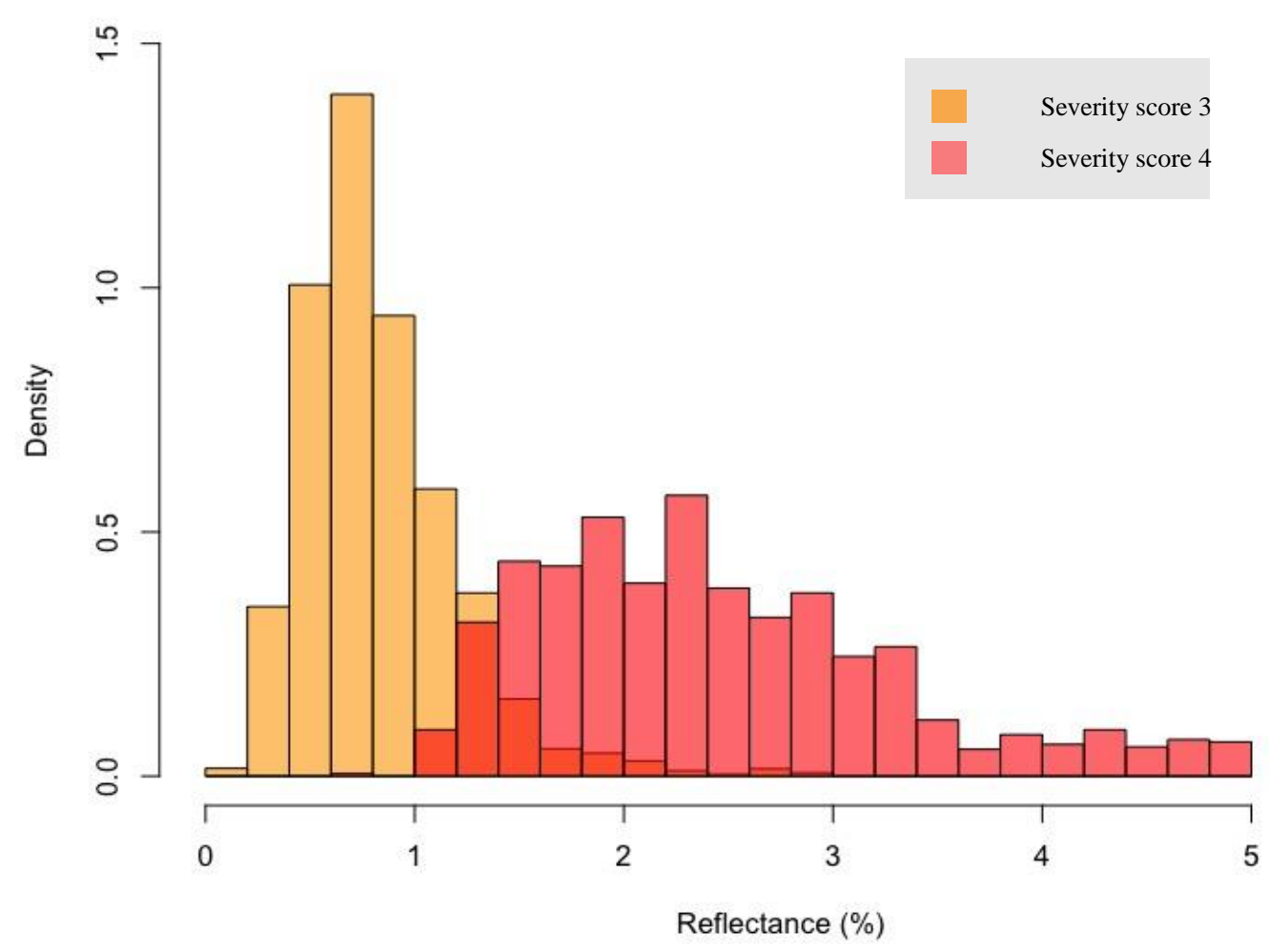

Figure 2 - Histogram showing the distribution of reflectance measurements of the Carn Brea charcoal. Bars are coloured to represent the different severity scores given to the sites along the burn scar, the red bars represent the sites given a severity score of 4 and the orange bars represent the sites given a severity score of 3.

A t-test was conducted on the reflectance values to compare all of the sites with a qualitative fire severity score of 3 , to site 7 , and then to site 8 , both of which had higher quantitative fire severity scores of 4 . There was a significant difference in the scores for all sites with a fire severity score of 3 $(\mathrm{M}=0.65, \mathrm{SD}=2.25)$ and site 7 (fire severity score 4) $(\mathrm{M}=2.56, \mathrm{SD}=0.84)$; $\mathrm{t}(499)=-45.733, p=<2.2 \mathrm{e}-$ 16 , and again when testing site 8 (fire severity score 4$)(\mathrm{M}=2.33, \mathrm{SD}=0.88)$ to the sites which a severity score of $3 ; \mathrm{t}(499)=-37.636, p=<2.2 \mathrm{e}-16$. These results suggest that quantitative fire severity scores do correspond to quantitative charcoal reflectance measurements; where the higher the charcoal reflectance the higher the qualitative fire severity score. Therefore, we suggest that charcoal reflectance measurements taken from burned areas may provide a useful quantitative means to assess aspects of fire severity that link more directly to aspects of fire behaviour (e.g. see Belcher and Hudspith, 2016; Hudspith et al., 2017) than existing qualitative fire severity scores. We aim to continue to develop this approach in the hope that it might be able to aid our understanding of post-fire recovery following fire events.

\section{Acknowledgments}

SLN is funded by the Natural Environment Research Council [NE/L002434/1] as part of the GW4+ Doctoral Training Partnership (http://www.nercgw4plus.ac.uk/). CMB acknowledges a European Research Council Starter Grant ERC-2013-StG-335891-ECOFLAM (awarded to CMB). We thank Dr MJ Grosvenor and Dr SJ Baker for assistance in the field, and Dr CA Boulton for assistance with R. 


\section{References}

Belcher CM, Hudspith VA (2016) The formation of charcoal reflectance and its potential use in postfire assessments. International Journal of Wildland Fire, 25(7), 775-779

BBC. (2015) 'Carn Brea gorse fire land 'will take years to recover', http://www.bbc.co.uk/news/ukengland-cornwall-32955448

Cohen-Ofri I, Weiner L, Boaretto E, Mintz G, Weiner S (2006) Modern and fossil charcoal: aspects of structure and diagenesis. Journal of archaeological science, 33(3): 428-439

Hudspith VA, Belcher CM, Yearsley JM (2014) Charring temperatures are driven by the fuel types burned in a peatland wildfire. Frontiers in Plant Science, 5(December), 714. http://doi.org/10.3389/fpls.2014.00714

Hudspith VA, Belcher CM, Barnes J, Dash CB, Kelly R, Hu FS (2017) Charcoal reflectance suggests heating duration and fuel moisture affected burn severity in four Alaskan tundra wildfires. International Journal of Wildland Fire, 26(4), pp.306-316.

Lowden L, Hull T (2013) Flammability behaviour of wood and a review of the methods for its reduction. Fire Science Reviews, 2(1), 4. http://doi.org/10.1186/2193-0414-2-4

Ryan K, Noste N (1985) Evaluating prescribed fires (230-238) in: JE Lotan et al. (tech. coor) Proceedings-Symposium and Workshop on Wilderness Fire. USDA Forest Service Intermountain Forest and Range Experiment Station, General Technical Report INT-182.

The Heritage Journal (2015) 'Carn Brea blaze - an opportunity for investigation?' https://heritageaction.wordpress.com/2015/05/28/carn-brea-blaze-an-opportunity-for-investigation. 